\title{
Genome wide association studies (GWAS) of element contents in grain with a special focus on zinc and iron in a world collection of barley (Hordeum vulgare L.)
}

\author{
Sanjaya Gyawali a, 1, *, Marinus L. Otte ${ }^{c}$, Shiaoman Chao ${ }^{b}$, Abderazzek Jilal ${ }^{\mathrm{d}}$, \\ Donna L. Jacob ${ }^{c}$, Reda Amezrou ${ }^{a}$, Ramesh Pal Singh Verma ${ }^{a}$ \\ a Biodiversity and Integrated Gene Management Program (BIGM), ICARDA, Rabat, Morocco \\ b USDA-ARS Cereal Crops Research Unit, Fargo, ND 58102-2765, USA \\ c Department of Biological Sciences, North Dakota State University, Fargo, ND 58108-6050, USA \\ ${ }^{\mathrm{d}}$ Institut National de la Recherche Agronomique (INRA) Maroc, Rabat, Morocco
}

\section{A R T I C L E I N F O}

\section{Article history:}

Received 23 May 2017

Received in revised form

29 August 2017

Accepted 30 August 2017

Available online 1 September 2017

\section{Keywords:}

Barley

Element

$\mathrm{Fe}$

GWAS

Marker

QTL

SNP

$\mathrm{Zn}$

\begin{abstract}
A B S T R A C T
Genome wide association studies (GWAS) were carried out to map Quantitative Trait Loci (QTL) associated with element contents in the grain using 336 spring barley. Of the elements analyzed, Fe content ranged from 21.9 to $91.0 \mathrm{mg} \mathrm{kg}^{-1}$, Zn from 10.4 to $54.5 \mathrm{mg} \mathrm{kg}^{-1}$, Ba from 0.2 to 8.9 , Ca from 186.4 to 977.5 , Cu from 1.5 to 9.8, $\mathrm{K}$ from 353.2 to 7721.5, Mg from 1049.8 to 2024.2, Mn from 8.1 to 22.9, Na from 55.9 to 627.9, P from 2272.9 to 5428.8 , S from 880.7 to 1898.0 , Si from 19.1 to 663.2 , and Sr from 0.35 to $2.62 \mathrm{mg} \mathrm{kg}^{-1}$. GWAS were carried out using 6519 SNP markers and multiple elements in MLM:PCA + K model in TASSEL software. Population analyses showed two sub-populations, primarily based on row types. GWAS for row types showed association with INTERMEDIUM-C, a modifier gene for lateral spikelet fertility in the $4 \mathrm{H}$ chromosome, validating current GWAS approach. GWAS also showed that $2 \mathrm{QTL}$ for Ba, 2 for $\mathrm{Ca}, 4$ for $\mathrm{Cu}, 11$ for Fe, 2 for K, 3 for $\mathrm{Mg}, 6$ for Mn, 4 for Na, 3 for S, 5 for Si, and 3 for Zn were mapped in barley chromosomes. The QTL identified in the current study are valuable for breeding nutrient dense barley cultivars in the future, especially $\mathrm{Zn}$ and Fe.
\end{abstract}

() 2017 Elsevier Ltd. All rights reserved.

\section{Introduction}

Three billion people around the world suffer from element deficiencies and malnutrition (Welch and Graham, 2004). Deficiencies of elements, especially iron (Fe), zinc ( $\mathrm{Zn})$ magnesium $(\mathrm{Mg})$, phosphorous (P), potassium (K), selenium (Se), and copper (C) are the major causes of over $65 \%$ of childhood deaths worldwide (Welch and Graham, 2004). Fe and Zn are particularly important for all living organisms, including humans, and cause several

\footnotetext{
* Corresponding author. Current address: 222 Agriculture Building, 66 Dafoe road, Plant Science Department, University of Manitoba, Winnipeg, R3T 2N2, MB, Canada.

E-mail addresses: gyawalisanjaya@gmail.com (S. Gyawali), marinus.otte@ndsu. edu (M.L. Otte), shiaoman.chao@ars.usda.gov (S. Chao), abderrazek_2001@yahoo. fr (A. Jilal), donnajacob1969@gmail.com (D.L. Jacob), reddamez@gmail.com (R. Amezrou), r.verma@cgiar.org (R.P.S. Verma).

${ }^{1}$ Current address: Plant Science Department, University of Manitoba, Winnipeg, MB, Canada.
}

deficiencies related human diseases (Marler and Wallin, 2006). Fe deficiency affects two billion people globally (Stoltzfus and Dreyfuss, 1998). Similarly, Zn deficiency affects one third of world population (Sandstead, 1991). Both Fe and Zn deficiencies pose a particular threat to human health in developing countries (WHO, 2002). Fe is the major component of hemoglobin responsible for oxygen and carbon dioxide transport during respiration, maintenance of blood acid-base ratio, the metabolism of body energy, and contributes to several immunological functions. Likewise, $\mathrm{Zn}$ has important roles in several metabolic functions including accelerated growth, body's immune responses and synthesis of several enzymes such as DNA polymerases, carbonic anhydrases and alkaline phosphatases (Prasad, 1991). Rapid changes in food habits and nutritive values of modern food in terms of micronutrients have contributed to element deficiency related problems. A comparison of historic genotypes of food crops with modern cultivars suggests that their nutritional value has drastically changed, with reduced mineral contents in modern small grains and vegetables 
compared to food produced 70 years ago (Marler and Wallin, 2006). Monasterio and Graham (2000) reported that the Fe and Zn contents declined gradually in wheat germplasm as an effect of modern plant breeding approaches during 1945-1999. Similarly, the development of soft white wheat has led to a decrease in element contents in this wheat class (Murphy et al., 2008). Declines in mineral contents in modern food have resulted in an increase of mineral deficiency associated diseases, such as heart conditions, chronic bronchitis, asthma, tinnitus, and bone deformities (Marler and Wallin, 2006).

Barley (Hordeum vulgare L.) is one of the major staple foods in several regions of the world, including the highlands of Asia, North and East Africa, the Andean countries, and the Baltic States (ElHaramein and Grando, 2010). Barley is one of the major cereals after rice, wheat, and maize by area and production (FAOStat, 2014). Around $3.7 \%$ of total barley production is used as human food annually worldwide, but in some countries, like in Morocco, Ethiopia and Eritrea, barley comprise as high as $60 \%$ of total food production (Newman and Newman, 2006).

Of the three strategies for resolving nutritional deficiencies in food crops: biofortification, food fortification, and mineral supplement, biofortification is the cheapest and most accessible (Welch and Graham, 2004). Barley grain contains about 65-68\% starch, $10-17 \%$ protein, $4-9 \% \beta$-glucan, $2-3 \%$ free lipids, and $1.5-2.5 \%$ minerals (Quinde et al., 2004). Barley is less sensitive to both Fe and $\mathrm{Zn}$ deficiencies, because it has genes involved in the mobilization and uptake of Fe and $\mathrm{Zn}$. Other mega crops, such as rice, lack that capability (Nakanishi et al., 2000; Takahashi et al., 1999). The genes, including HvNAS1, HvNAAT-A, HvNAAT-B, HvDMAS1, IDS2, and IDS3, are up-regulated in Fe-deficient barley roots (Nakanishi et al., 2000; Takahashi et al., 1999). These observations suggest that there is a tremendous opportunity to improve Fe and $\mathrm{Zn}$ contents in barley grains using biofortification, and potentially also in other crops, such as rice (Masuda et al., 2008). The first step towards the exploitation of biofortification of elements in barley is to assess the status of element concentrations in the kernel and map Quantitative Trait Loci (QTL) associated with element uptake in plants. Mapping QTL associated with elements in barley is just beginning. Lonergan et al. (2009) mapped QTL for $\mathrm{Zn}$ uptake in $1 \mathrm{H}, 2 \mathrm{H}$ and $5 \mathrm{H}$ barley chromosomes using double haploid (DH) population. Sadeghzadeh et al. (2010) mapped Zn accumulating QTL on the $2 \mathrm{H}$, $3 \mathrm{H}$ and $4 \mathrm{H}$ barley chromosomes using a $\mathrm{DH}$ population. A few studies showed genetic variation in Fe uptake in barley, however QTL for Fe uptake and other elements are scant. Mamo et al. (2014) mapped QTL for Zn and Fe uptakes in barley using the genomewide association studies (GWAS) approach. ICARDA's barley program aims to improve barley genetic resources on a global scale. The objectives of the current study were to (1) assess variability of element uptake in a world collection of cultivated barley germplasms at ICARDA and to (2) map QTL associated with element uptake in barley grain using the GWAS approach.

\section{Materials and methods}

\subsection{Plant materials}

The Genome Wide Association Study reported here, which we named Association Mapping panel 2014 (AM-2014) comprised a total of 336 genotypes. Out of these, 230 genotypes were collected from the low input barley breeding program (genotypes adapted for biotic and abiotic stress tolerances) of ICARDA, 82 from the high input barley breeding program (genotypes adapted to favorable conditions) and the remaining 26 genotypes were frequently used in both programs (Supplement Table S1). Based on grain types, 276 genotypes in the AM-2014 were hulled and 60 were hull-less barley. In terms of row type, 136 genotypes were two-rowed and 200 were six-rowed. The majority of the barley genotypes was collected from barley breeding programs of ICARDA (advanced breeding lines), but also represented genotypes from different sources, including the Genetic Resource Unit (Gene Bank) of ICARDA and barley breeding programs from India, Australia, USA, Canada, and Morocco. The majority of the genotypes of AM-2014 were advanced breeding lines and release cultivars; a few were landraces. The AM-2014 panel was described in detail at the molecular and phenotypic level by Amezrou et al. (2017). The passport data of AM-2014 are presented in Supplement Table S1.

\subsection{Phenotyping}

Two sets each of barley seed samples were obtained from two field experiments that were conducted in Marchouch $(\mathrm{MCH})$ $\left(33^{\circ} 33^{\prime} 38.2^{\prime \prime} \mathrm{N} 6^{\circ} 41^{\prime} 24.7^{\prime \prime} \mathrm{W}\right)$, and Jemma-Shaim (JS) $\left(32^{\circ} 21^{\prime} 09.3^{\prime \prime} \mathrm{N}\right.$ $8^{\circ} 50^{\prime} 32.0^{\prime \prime} \mathrm{W}$ ) Research Stations in Morocco. The experiments were conducted in an alpha lattice design, replicated twice with 10 genotypes in each block. In 2015, the 336 barley genotypes were evaluated for various phenotypic, agronomic traits in the field. From each genotype, three spikes were harvested at maturity, kept in labelled envelopes, and sun dried for two days. To eliminate any contamination of metals, grains were harvested and cleaned manually by hand, and stored in paper bags.

\subsection{Element analysis}

Analysis of multiple elements at the same time in the same samples, using equipment such as Inductively Coupled Plasma spectrometry (ICP), can provide information about elements in addition to those of immediate interest, and about their interactions (Markert, 1992; Otte and Jacob, 2005). For example, a higher content of one essential nutrient may coincide with a lower content of another essential nutrient. With a view to get some insight into such interactions, we wanted to analyze at least a subset of the samples for more than just Fe and Zn. However, because of the large number of samples and the amount of funding available, we could not do this for all samples. We therefore decided to use the samples from JS for analysis by ICP (NDSU, Fargo, ND, USA), and the samples from MCH for analysis for Fe and Zn only by Atomic Absorption Spectrometry AAS (INRA, Morocco).

Grain samples from the experiment in Jemma Shiam (JS) were used for multi-element analysis by Inductively Coupled Plasma (ICP) analysis in an augmented design with checks repeated multiple times. Among the checks, Rihane-03 was repeated six times while Tichedrette, Alanda-01, WI2291, Harmal, Nawair-01, Petunia 1, Jyoti, Lakhan (K226), Geetanjali (K1149), DWR28, RD2668, DWRUB52, RD2668_1, and Furat-1 each were repeated three times. The element analyses were conducted in the Department of Biological Sciences, North Dakota State University (NDSU), Fargo, ND. Barley grain samples were randomized, powdered, and homogenized using mortar, pestle, and liquid nitrogen. Samples were dissolved using a CEM Xpress microwave digester NC, USA and $55 \mathrm{ml}$ PFA venting vessels with the following method: $250 \mathrm{mg}, 1: 1 \mathrm{nitric}$ acid and DI water solution (10 total $\mathrm{ml}$ ), overnight pre-digestion, then microwaved at $200{ }^{\circ} \mathrm{C}$ for 25 min after 20 min ramping from ambient temperature. Digested samples and blanks were analyzed using Spectro Genesis SOP ICP-OES (Spectro Analytical Instrument GmbH, Germany) with SmartAnalyzer Vision software and Optimist nebulizer with a cyclonic spray chamber. Quality control included digestion and analysis of certified reference material (Maize GBW10012), the ICALization internal standard procedure, analysis of an external standard, control calibration verification, and analysis of duplicate samples. Barley samples from 
JS were analyzed for 31 elements in the grain, but only $\mathrm{Ba}, \mathrm{Ca}, \mathrm{Cu}, \mathrm{Fe}$, $\mathrm{Mg}, \mathrm{Mn}, \mathrm{Na}, \mathrm{P}, \mathrm{S}, \mathrm{Si}, \mathrm{Sr}$, and $\mathrm{Zn}$ were above the method detection limit (MDL) in all 336 barley genotypes, therefore data on these elements were further used for GWAS. The MDL was calculated by using the following formula: number of sub populations was determined using the $\Delta k$ (Evanno et al., 2005). The population structure was further investigated using principal coordinate analysis. The kinship matrix (K) was estimated in TASSEL and used as covariate to control false positives in the marker trait analysis.

$M D L=\frac{3 x \operatorname{stdev}(\text { calibration water blank) } x \text { extraction volume } x \text { dilution factor }}{\text { mean dry weight }}$

Grain samples from the experiment conducted in Marchouch $(\mathrm{MCH})$ station were analyzed only for Fe and $\mathrm{Zn}$. The design of the field experiment and grain sampling were the same as for Jemma Shiam (JS) used for multiple element analysis described above. Sample preparation and analysis were conducted at the Institut National de la Researche Agronomique-Maroc (INRA-Maroc) following Miller and Rutzke (2003), as follows. Grain samples were dried in an oven for about $16 \mathrm{~h}$ (overnight) at $105^{\circ} \mathrm{C}$ then at $200^{\circ} \mathrm{C}$, after which the temperature was gradually increased to $450{ }^{\circ} \mathrm{C}$ for $16 \mathrm{~h}$. The remaining ash was then digested in $4 \mathrm{ml}$ of nitric acid to decompose the organic matter, and the remaining inorganic residue dissolved in $5 \mathrm{ml}$ of diluted hydrochloric acid (9.25\%) following the protocol of Heath Canada (1985). Internationally certified reference material and black checks were used to maintain analytical quality assurance.

\subsection{Statistical analysis elements}

The descriptive analysis (mean, standard deviation and range) were estimated in SAS v.10 (SAS Institute, 1999) statistical software package using PROC SUMMARY command. The element content of barley grains was subjected to ANOVA using augmented block design. The ANOVA was performed using PROC GLM of the SAS. The element contents of test genotypes were differentiated by Fisher's least significant difference (LSD) $(P=0.05)$ based on the standard error of the mean difference of repeated checks, that were used in the experiment.

\subsection{Single Nucleotide Polymorphism (SNP) genotyping}

SNP genotyping of AM-2014 was reported by Amezrou et al. (2017). In brief, single barley plants of each line were grown in a greenhouse and the leaf tissue was lyophilized. Genomic DNA was extracted using the method described in Slotta et al. (2008). The lines were genotyped using the 9K iSelect SNP array based on Illumina's Inifinium Assay (Illumina, San Diego, CA, USA) at Cereal Crop Research Unit, USDA-ARS, Fargo, ND. The obtained SNP data were further filtered for (a) a minor allele frequency of 0.05 , (b) rate of missing values above $10 \%$.

\subsection{Population structure}

In order to account for false positives in GWAS, population structure was investigated in the panel using the program STRUCTURE (version 2.3.4) (Pritchard et al., 2000) Membership probability for each barley genotype to a number of hypothetical subpopulations (k) was estimated using SNP markers. Subpopulations 1-7 were tested using an admixture model. The program was first run for a burn-in period of 100,000 while the posterior probabilities were estimated using the Markov Chain Monte Carlo (MCMC) method with 100,000 repetitions. The most likely

\subsection{SNP-element association analysis}

Marker-trait association studies were carried out in TASSEL version 4 (Bradbury et al., 2007). In TASSEL, models: naive GLM, $\mathrm{GLM}+\mathrm{Q}, \mathrm{GLM}+\mathrm{PCA}, \mathrm{MLM}+\mathrm{Q}+\mathrm{K}, \mathrm{MLM}+\mathrm{PCA}+\mathrm{K}$ were tested for discovering true marker-trait associations and effectiveness in controlling false positives. Results showed that GLM models were not good enough to control the false positives (data not presented) while both MLM $+\mathrm{Q}+\mathrm{K}$ and MLM $+\mathrm{PCA}+\mathrm{K}$ were found effective for finding true associations. Further, the results of both MLM models were similar, therefore MLM + PCA + K was used in the current study. SNP alleles $<0.05$ frequency were treated as minor alleles, therefore such rare variants having minor alleles were removed from the analysis. Variants with $>10 \%$ missing SNPs were also discarded from the analysis. The pFDR $(q<0.05)$ was applied in order to test the statistical significance of multiple comparisons of all detected markers according to Storey (2002). The output data included $R^{2}$ (\% phenotypic variation explained by significant markers), the additive effects where a positive value indicates the presence of alleles that enhance the uptake of elements and a negative value indicated presence of alleles that reduce the elements in the grain. The sequence of significant SNPs were subjected to BLAST searches, in order to annotate predicted genes.

\section{Results}

\subsection{Element analyses including $\mathrm{Zn}$ and $\mathrm{Fe}$}

The results of ANOVA of element contents by 336 barley genotypes are presented in Table 1 . Except for $\mathrm{Mg}$ and $\mathrm{Si}$, genotypes showed highly significant differences in element contents. The passport data and element content of individual barley genotypes are presented in Supplement Table S1. The summary statistics on element contents by 336 barley genotypes from JS and MCH in 2015 are presented in Supplement Table S2. Likewise, the summary statistics of repeated checks are presented in Supplement Table S3. The box and whisker plots of element contents are also shown in Fig. 1A-D. Higher Fe and $\mathrm{Zn}$ uptake were observed in $\mathrm{MCH}$ compared to JS locations, however the range of both $\mathrm{Zn}$ and Fe was higher in JS (Fig. 1A).

\subsection{Single Nucleotide Polymorphism (SNP) and linkage disequilibrium (LD) in AM-2014 panel}

The details of SNP markers used in the current study were described by Amezrou et al. (2017). In brief, of 9K SNP markers genotyped in 336 barley genotypes, a total of 6940 genome wide SNPs, were of high quality. Further filtering for $>10 \%$ missing data and $<0.05$ minor allele frequency resulted into 6519 SNPs which were used in further analysis (PCA and GWAS). The genome wide LD was estimated at $3.58 \mathrm{cM}$ in the current AM-2014 panel, while 
Table 1

Analysis of variance of element contents of barley grains in a world collection of 336 barley genotypes by ICARDA in 2015 from Jemma Shiam, Morocco.

\begin{tabular}{|c|c|c|c|c|c|c|c|c|c|c|c|c|c|c|}
\hline \multirow[t]{2}{*}{ Source of variation } & \multirow[t]{2}{*}{ df } & $\mathrm{Ba}$ & $\mathrm{Ca}$ & $\mathrm{Cu}$ & $\mathrm{Fe}$ & $\mathrm{K}$ & $\mathrm{Mg}$ & Mn & $\mathrm{Na}$ & $\mathrm{P}$ & $\mathrm{S}$ & $\mathrm{Si}$ & $\mathrm{Sr}$ & $\mathrm{Zn}$ \\
\hline & & \multicolumn{13}{|l|}{$P$-Value } \\
\hline Block & 16 & 0.109 & 0.013 & 0.002 & 0.32 & $<0.001$ & 0.725 & 0.490 & 0.01 & 0.186 & 0.494 & 0.458 & $<0.001$ & 0.739 \\
\hline Genotypes & 341 & $<0.001$ & 0.003 & $<0.001$ & 0.03 & $<0.001$ & 0.102 & 0.002 & $<0.001$ & $<0.001$ & 0.002 & 0.155 & $<0.001$ & 0.047 \\
\hline
\end{tabular}
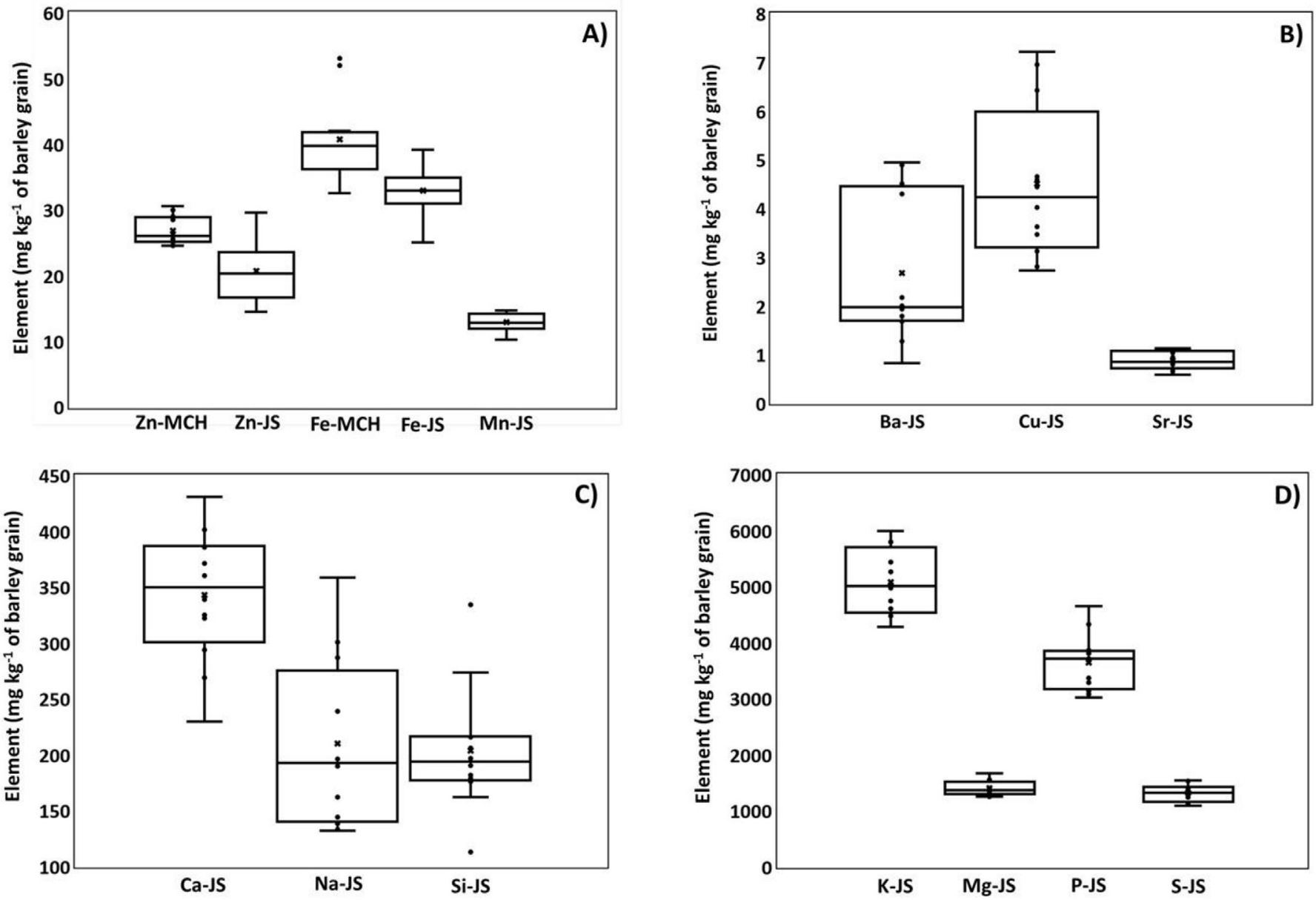

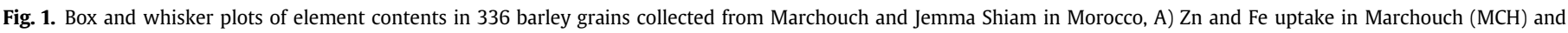
Jemma Shiam (JS), and Mn in Jemma Shiam, B) Ba, Cu, and Sr uptake in Jemma Shiam, C) Ca, Na, and Si uptake in Jemma Shiam, D) K, Mg, P and S uptake in Jemma Shiam.

LD decay varied between two-and six-rowed subpopulations. LD decay was recorded as $3.91 \mathrm{cM}$ for the two-rowed sub-populations and $2.26 \mathrm{cM}$ for the six-rowed sub-populations.

\subsection{Population structure}

Principal Coordinate Analysis (PCoA) and Population Structure were implemented to investigate the subpopulation in AM-2014. Both approaches showed two sub-populations, primarily based on row types in the current mapping panel (Figs. 2 and 3). Based on a 0.2 probability threshold in structure analysis, nearly $36 \%$ of barley genotypes showed admixture (Fig. 2). Similarly, PCoA clearly showed two distinct sub-populations in the current mapping panel based on row types, however, some overlap between the tworowed and six-rowed clusters was also apparent (Fig. 3).

\subsection{Genome wide association studies (GWAS) of row types}

The results of GWAS of row type, SNP state, significant SNPs, marker positions, $R^{2}$, additive effects, allele frequency and predicted gene annotations are presented in Table 2. Multiple SNPs were highly significant $(q<0.05)$ in $1 \mathrm{H}, 3 \mathrm{H}, 4 \mathrm{H}, 6 \mathrm{H}$, and $7 \mathrm{H}$ chromosomes. The $R^{2}$ of these significant SNPs varied from 3.3 to $8.0 \%$. The gene annotation using the BLAST search resulted in MATH domain-containing proteins (SNP: SCRI_RS_171501), PhytanoylCoA dioxygenase 1(SNP: 11_20606), Glutathione S-transferase 3(SNP: 11_20422), Phytochrome A (SNP:12_30864), KNOTTED-1like homeobox protein d (knox1d) (SNP: SCRI_RS_145412), and IQ-Domain-1(SNP: 12_20803).

\subsection{Genome wide association studies (GWAS) of multiple elements}

The results, SNP state, significant SNPs, marker positions, $R^{2}$, 


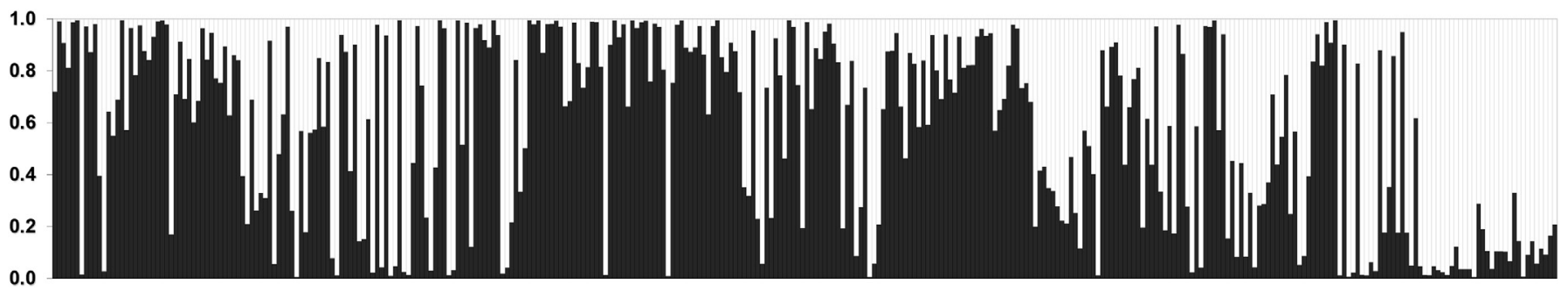

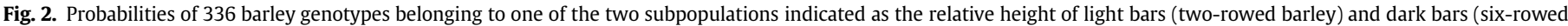
barley).

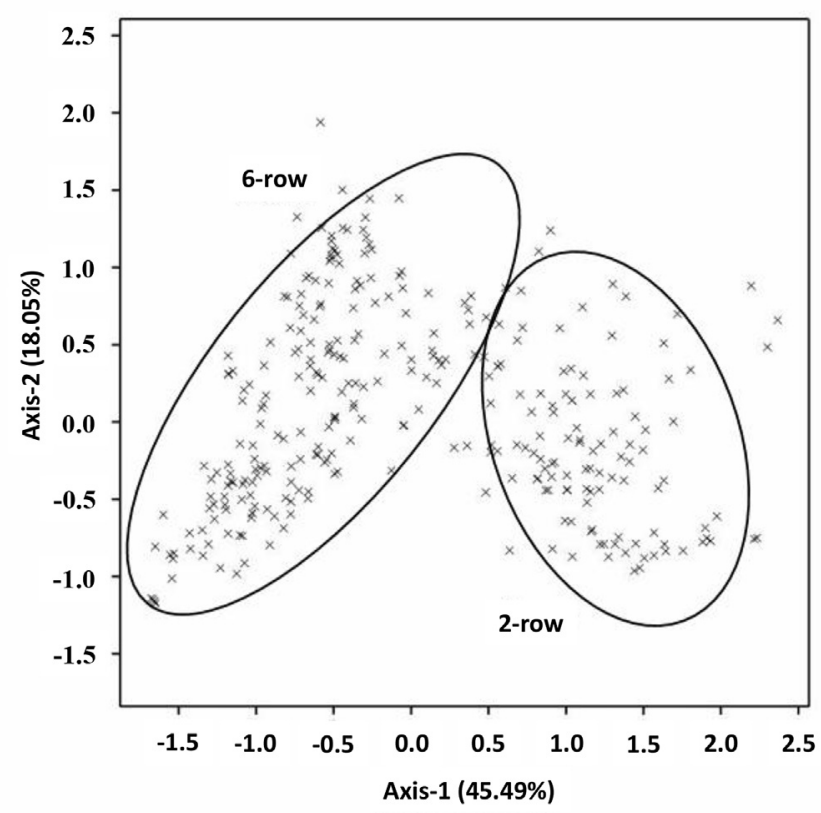

Fig. 3. Principal Coordinate Analysis ( $\mathrm{PCoA})$ based on genetic distance computed for 336 individuals (6-row $=6$-rowed barley, 2 -row $=2$-rowed barley).

additive effects, allele frequency and predicted gene annotations, of GWAS of 13 elements (including $\mathrm{Zn}$ and $\mathrm{Fe}$ ) in JS and $\mathrm{Zn}$ and Fe only in $\mathrm{MCH}$ locations are presented in Table 3. Some SNPs were significant for multiple elements while other SNPs were significant for specific element uptake only. In the case where a single SNP was significant for multiple elements, QTL was designated as E-CH-SNP Position, where E-represented uptake of multiple elements, $\mathrm{CH}$ represented barley chromosome number followed by a number that represented SNP position in given chromosome. For example, E-3H-66.15 (SNP: 11_10813) was significant for $\mathrm{Cu}, \mathrm{Mg}, \mathrm{Na}, \mathrm{S}$, and $\mathrm{Zn}$ in JS, while $\mathrm{Fe}-1 \mathrm{H}-57.85$ (SNP: SCRI_RS_237999) was significant only for Fe in $\mathrm{MCH}$ (Table 3).

Two QTL, $B a-3 H-15.52$ and $B a-5 H-90.22$, were in the $3 \mathrm{H}$ and $5 \mathrm{H}$ chromosomes from JS, (Table 3 ). In $5 \mathrm{H}$, three SNPs were significant at $90.22 \mathrm{cM}$ which were highly significant $(q<0.01)$ while five SNPs with unknown positions were also significant in $5 \mathrm{H}, 6 \mathrm{H}$, and $7 \mathrm{H}$ chromosomes. The $R^{2}$ and additive effects of these QTL ranged from 3.6 to $7.7 \%$ and $-1.06-0.73 \mathrm{mg} \mathrm{kg}^{-1}$. Two QTL, $\mathrm{Ca}-2 \mathrm{H}-126.56$ and $E$ $3 H-153.39$ were significant for Ca uptake, while QTL E-3H-153.39 was also significant for $\mathrm{K}$. The variation explained by these QTL was $3.5 \%$, while the additive effects ranged from $-42.17-40.99 \mathrm{mg} \mathrm{kg}^{-1}$. Four QTL, E-3H-66.15, Cu-6H-50.61, Cu-6H-52.2, and Cu-6H-58.91, were significant for $\mathrm{Cu}$. E-3H-66.15 detected in the $3 \mathrm{H}$ chromosome; the remaining in the $6 \mathrm{H}$ chromosome. E-3H-66.15 was significant for $\mathrm{Cu}, \mathrm{Mg}, \mathrm{Na}, \mathrm{S}$, and $\mathrm{Zn}$ uptake from $\mathrm{JS}$. The $R^{2}$ of these QTL ranged from 3.6 to $3.9 \%$ and additive effects ranged from -0.77 to $0.70 \mathrm{mg} \mathrm{kg}^{-1}$. Two QTL, $E-3 H-153.39$ and $K-5 H-95.65$, were significant for $\mathrm{K}$, while 3 SNP markers with unknown positions in $4 \mathrm{H}$, $5 \mathrm{H}$, and $7 \mathrm{H}$ were also significant for this element. The $R^{2}$ of these QTL ranged from 3.6 to $8.1 \%$ and additive effects ranged from -266.63 to $-424.11 \mathrm{mg} \mathrm{kg}^{-1}$. Three QTL, $M g-2 H-66.61, \mathrm{E}-3 \mathrm{H}-$ 66.15, and $E-7 H-95.02$ were significant for $\mathrm{Mg}$. Of these, $E-3 H-66.61$ (Cu, Mg, Na, S, and $\mathrm{Zn}$ ) and E-7H-95.02 (Mg, Mn, and Si) were significant for multiple elements. Five QTL, $M n-3 H-74.41, M n-4 H-$ 60.70, $M n-7 H-82.16, M n-7 H-91.73$, and $E-7 H-91.73$ were significant for Mn while one SNP with unknown marker position was also significant for Mn. The $R^{2}$ of these QTL ranged from 3.5 to $5.2 \%$ and additive effects ranged from $-2.03-1.13 \mathrm{mg} \mathrm{kg}^{-1}$. For Na, four QTL, E-3H-66.15, Na-5H-1.12, E-5H-44.99, and $\mathrm{Na}-7 \mathrm{H}-82.89$ were in $3 \mathrm{H}$, $5 \mathrm{H}$, and $7 \mathrm{H}$ chromosomes. One SNP with unknown marker position, SCRI_RS_185604, was significant for Na too. The $R^{2}$ of these QTL ranged from 3.7 to $4.8 \%$ and additive effects from 45.91 to $333.53 \mathrm{mg} \mathrm{kg}^{-1}$. Only one SNP marker, SCRI_RS_140936 was significant for Se, but the marker position of this SNP was unknown. Five QTL, namely Si-4H-88.81, Si-4H-103.38, Si-5H-185.05, Si-7H81.7, and $E-7 \mathrm{H}-95.09$, were significant in $4 \mathrm{H}, 5 \mathrm{H}$, and $7 \mathrm{H}$ chromosomes for $\mathrm{Si}$ while three SNPs with unknown marker positions were also significant for Si. The $R^{2}$ of these QTL ranged from 3.4 to $5.7 \%$ and additive effects from $-78.14-98.91 \mathrm{mg} \mathrm{kg}^{-1}$. Three QTL, $S$ $1 \mathrm{H}-50, E-3 H-66.15$, and $S-4 H-117.13$ were significant in the $1 \mathrm{H}, 3 \mathrm{H}$, and $4 \mathrm{H}$ chromosomes for $\mathrm{S}$. Three additional SNPs were also significant for $\mathrm{S}$ but their marker positions were unknown. The $R^{2}$ of these QTL ranged from 3.5 to $4.1 \%$ and additive effects from $-82.0-117.91 \mathrm{mg} \mathrm{kg}^{-1}$.

\subsection{Genome wide association studies (GWAS) of $\mathrm{Zn}$ and Fe}

The GWAS results of $\mathrm{Zn}$ and Fe from JS and $\mathrm{MCH}$ locations are presented in Table 3. Three QTL regions were significant for $\mathrm{Zn}$, of which two were from JS and the other from MCH. E-3H-66.15 and $E$ $5 \mathrm{H}-44.99$ were significant in the $3 \mathrm{H}$ and $5 \mathrm{H}$ chromosomes from JS while $\mathrm{Zn}-2 \mathrm{H}-87.34$ was significant in the $2 \mathrm{H}$ chromosome of $\mathrm{MCH}$. Of these QTL, E-3H-66.15 and E-5H-44.99 were also significant for other elements, including $\mathrm{Cu}, \mathrm{Mg}, \mathrm{Na}, \mathrm{S}$, and $\mathrm{Na}$. The $R^{2}$ of these QTL ranged from 3.5 to $4.9 \%$ and additive effects from $-3.5-2.38 \mathrm{mg} \mathrm{kg}^{-1}$. Ten QTL were significant for Fe from JS and $\mathrm{MCH}$. In JS, three QTL, namely Fe-2H-84.74, Fe-2H-139.62, and $\mathrm{Fe}-4 \mathrm{H}-67.91$ were significant in the $2 \mathrm{H}$ and $4 \mathrm{H}$ chromosomes. In contrast, seven QTL, namely $\mathrm{Fe}-1 \mathrm{H}-54.5, \mathrm{Fe}-1 \mathrm{H}-57.85$, $\mathrm{Fe}-1 \mathrm{H}-90.04$, $\mathrm{Fe}-2 \mathrm{H}-84.74, \mathrm{Fe}-4 \mathrm{H}-53.87, \mathrm{E}-4 \mathrm{H}-54.95, \mathrm{Fe}-6 \mathrm{H}-102.03$, and $\mathrm{Fe}-7 \mathrm{H}-$ 17.62 were significant in the $1 \mathrm{H}, 2 \mathrm{H}, 4 \mathrm{H}, 6 \mathrm{H}$, and $7 \mathrm{H}$ chromosomes in $\mathrm{MCH}$. Of these, QTL $\mathrm{Fe}-2 \mathrm{H}-84.74$ was significant in both JS and $\mathrm{MCH}$ locations. Five SNPs with the unknown marker position were also significant for Fe. The $R^{2}$ of these QTL ranged from 3.3 to $5.0 \%$ and additive effects from $-12.9-6.15 \mathrm{mg} \mathrm{kg}^{-1}$. The predicted gene 
Table 2

Genome wide association studies of row types 336 genotypes of barley, and gene annotation of significant SNP markers using BLAST search.

\begin{tabular}{|c|c|c|c|c|c|c|c|c|c|}
\hline SNP ID & SNP & ${ }^{\mathrm{a}} \mathrm{CH}$ & cM & ${ }^{\mathrm{b}} P$-value & $R^{2}$ & $\begin{array}{l}\text { Additive } \\
\text { effect }\end{array}$ & $\begin{array}{l}\text { Allele } \\
\text { Frequency }\end{array}$ & ${ }^{\mathrm{c}}$ E-value & Gene annotation using BLAST search \\
\hline SCRI_RS_6913 & $\mathrm{A} / \mathrm{C}$ & $1 \mathrm{H}$ & 100.45 & $4.1 \mathrm{E}-07^{* *}$ & 8.0 & 1.030 & $A=314$ & $e_{-}$ & - \\
\hline SCRI_RS_171501 & $\mathrm{T} / \mathrm{C}$ & $1 \mathrm{H}$ & 101.05 & $1.4 \mathrm{E}-04^{*}$ & 4.4 & 0.689 & $C=304$ & $4.0 \mathrm{E}-24$ & MATH domain-containing protein \\
\hline SCRI_RS_66669 & $\mathrm{A} / \mathrm{C}$ & $1 \mathrm{H}$ & $\begin{array}{l}\text { d518942719- } \\
518942839\end{array}$ & $4.1 \mathrm{E}-07^{* *}$ & 8.0 & 1.039 & $A=314$ & - & - \\
\hline SCRI_RS_202425 & $\mathrm{A} / \mathrm{G}$ & $3 \mathrm{H}$ & 108.07 & $5.7 \mathrm{E}-05^{* *}$ & 5.0 & 0.623 & $A=268$ & - & - \\
\hline SCRI_RS_826 & $\mathrm{T} / \mathrm{C}$ & $3 \mathrm{H}$ & 82.19 & $6.2 \mathrm{E}-04^{*}$ & 3.6 & 0.570 & $C=199$ & - & - \\
\hline SCRI_RS_228486 & $\mathrm{A} / \mathrm{G}$ & $3 \mathrm{H}$ & 93.23 & $7.6 \mathrm{E}-04^{*}$ & 3.4 & -0.326 & $A=149$ & - & - \\
\hline SCRI_RS_7704 & $\mathrm{T} / \mathrm{C}$ & $4 \mathrm{H}$ & 26.35 & $1.0 \mathrm{E}-04^{*}$ & 4.6 & 0.573 & $C=266$ & - & - \\
\hline 11_20606 & $C / G$ & $4 \mathrm{H}$ & 31.14 & $5.5 \mathrm{E}-05^{* *}$ & 5.1 & 0.807 & $G=207$ & $5.0 \mathrm{E}-76$ & Phytanoyl-CoA dioxygenase 1 \\
\hline 11_21070 & $\mathrm{A} / \mathrm{C}$ & $4 \mathrm{H}$ & 31.14 & $1.8 \mathrm{E}-04^{*}$ & 4.4 & -0.681 & $A=134$ & - & - \\
\hline 11_20422 & $\mathrm{C} / \mathrm{G}$ & $4 \mathrm{H}$ & 31.45 & $2.3 \mathrm{E}-06^{* *}$ & 7.1 & -0.882 & $C=139$ & $5.0 \mathrm{E}-91$ & Glutathione S-transferase 3 \\
\hline 12_30864 & $\mathrm{A} / \mathrm{G}$ & $4 \mathrm{H}$ & 38.44 & $2.6 \mathrm{E}-04^{*}$ & 4.1 & 0.521 & $G=217$ & $1.0 \mathrm{E}-53$ & Phytochrome A \\
\hline SCRI_RS_145412 & $\mathrm{T} / \mathrm{C}$ & $4 \mathrm{H}$ & 42.89 & $1.6 \mathrm{E}-05^{* *}$ & 6.4 & 0.638 & $\mathrm{~T}=236$ & $1.0 \mathrm{E}-53$ & $\begin{array}{l}\text { KNOTTED-1-like homeobox protein d } \\
(\text { knox } 1 d)\end{array}$ \\
\hline 12_11063 & $\mathrm{A} / \mathrm{C}$ & $4 \mathrm{H}$ & 53.87 & $7.8 \mathrm{E}-04^{*}$ & 3.4 & -0.725 & $C=314$ & - & - \\
\hline SCRI_RS_237565 & $\mathrm{A} / \mathrm{C}$ & $6 \mathrm{H}$ & 1.4 & $9.9 \mathrm{E}-04$ & 3.3 & -0.382 & $C=262$ & - & - \\
\hline $12 \_20803$ & $\mathrm{~A} / \mathrm{G}$ & $7 \mathrm{H}$ & 28.98 & $2.4 \mathrm{E}-04^{*}$ & 4.1 & -0.628 & $A=285$ & $4.0 \mathrm{E}-14$ & IQ-Domain-1 \\
\hline
\end{tabular}

a $\mathrm{CH}$-Chromosome.

b $*, * *$ are significant SNP markers after FDR correction at 0.05 and 0.01 probability levels.

c E-value is the expected hits to find homology of SNP sequence to the given gene(s) in BLAST search.

d Physical position of the marker.

e Blast search either resulted into predicted protein or did not find any significant alignment.

annotation using SNP sequences in BLAST search was presented in Table S4. A diverse set of genes with known functions that were homologous to SNP sequences were reported while many of others SNP sequences had homology to several predicted proteins of unknown function.

\section{Discussion}

Among the graminaceous cereals, barley hosts several genes involved in the mobilization and uptake of Fe and $\mathrm{Zn}$ (NAS, NAAT, DMAS, IDS2, and IDS3), which other mega crops such as rice lack (Nakanishi et al., 2000; Takahashi et al., 1999). Higher levels of Zn and Fe were reported in barley landraces in a collection of ICARDA germplasm by El-Haramein and Grando (2010). In the study presented here, 336 barley genotypes of diverse origins, representing advanced lines, released cultivars, and landraces, were evaluated for the contents of $\mathrm{Fe}$ and $\mathrm{Zn}$ and 11 other elements from two large experiments in Morocco. We found $\mathrm{Zn}$ contents to range from 19.8 to $54.5 \mathrm{mg} \mathrm{kg}^{-1}$, and Fe contents from 37.0 to $90.0 \mathrm{mg} \mathrm{kg}^{-1}$. Our observations are in agreement with Ma et al. (2004), who reported Fe contents in barley grains of $24.6-63.3 \mathrm{mg} \mathrm{kg}^{-1}$ in Japanese barley and $21.0-83.0 \mathrm{mg} \mathrm{kg}^{-1}$ in American barley. Dick et al. (1985) reported a similar range of $\mathrm{Fe}\left(32.5-90.0 \mathrm{mg} \mathrm{kg}^{-1}\right)$ and $\mathrm{Zn}$ (19.2-53.5 mg kg-1) concentration in the grains of Canadian barley cultivars which is no departure from this study. However, Wu and Zhang (2002) reported higher Fe (50.05-114.53 $\mathrm{mg} \mathrm{kg}^{-1}$ ) and $\mathrm{Zn}$ (35.76-76.10 mg kg $\mathrm{k}^{-1}$ ) concentrations in the barley grains of eight cultivars in China. Higher $\mathrm{Zn}$ concentrations in the barley grains were reported by Hussain et al. (2016) and Sadeghzadeh et al. (2015) in a double haploid population of Clipper x Sahara. Higher variability of $\mathrm{Fe}$ and $\mathrm{Zn}$ concentrations in barley grains of landrace and wild barley are expected. Mamo et al. (2014) found higher variability in $\mathrm{Fe}$ (27.26-109.60 $\left.\mathrm{mg} \mathrm{kg}^{-1}\right)$ and $\mathrm{Zn}$ (19.69-87.42 $\mathrm{mg} \mathrm{kg}^{-1}$ ) concentrations in the barley grains of landraces originated from Ethiopia. In contrast, higher variabilities in Fe and Zn contents were reported by Yan et al. (2012), who found that Fe ranged from 10.8 to $329.1 \mathrm{mg} \mathrm{kg}^{-1}$ and $\mathrm{Zn}$ from 66.3 to $493.9 \mathrm{mg} \mathrm{kg}^{-1}$ among 92 wild genotypes (H. spontaneum) originating from Israel.

We validated the GWAS approach by mapping loci responsible for row type (fertility of lateral spikelets and tillering) in barley. Cuesta-Marcos et al. (2010) and Ramsay et al. (2011) reported that the INTERMEDIUM-C (INT-C) gene mapped in the 4HS chromosome plays vital role in fertility of lateral spikelets on the inflorescence and tillering in barley. Ramsay et al. (2011) reported that INT-C, which is an ortholog of the maize domestication gene TEOSINTE BRANCHED 1 (TB1), modulated the phenotypes imposed by VRS1 alleles in barley. They reported that two SNPs 11_20606 and 11_20422 at 4HS significantly correlated with INT-C in barley. Mamo et al. (2014) also reported at least one of the SNPs, 11_20606, correlated significantly with row types in GWAS. In the current study, 3 SNPs, 11_20606, 11_21070, and 11_20422, were significantly $(q<0.05)$ correlated with row types (fertility of lateral spikelets), including three other SNPs in the 4HS chromosome at the span of 38.44-53.87 cM. Likewise, Cuesta-Marcos et al. (2010) reported that row types in barley were modulated by the interactions in VRS1 and several alleles present in the $1 \mathrm{H}, 2 \mathrm{H}, 4 \mathrm{H}$, and $5 \mathrm{H}$ chromosomes. Among them, we found at least two alleles reported by Cuesta-Marcos et al. (2010) in 1HL and 4HS to be highly correlated with row types in our study. The gene annotation using the BLAST search (Table 2) revealed the four most significant SNPs: 11_20606, 11_20422, 12_30864, and SCRI_RS_145412 are genes orthologous to rice LOC_Os03g50040 (Phytanoyl-CoA dioxygenase), LOC_Os03g50130 (microsomal glutathione S-transferase 3) (Ramsay et al., 2011), a gene orthologous to wheat and Brachypodium distachyon LOC100836209 (Phytochrome A), and a gene orthologous to wheat KNOTTED-1-like homeobox protein $\mathrm{d}($ knox $1 d)$. These results validate that the GWAS approach employed for row types and element contents in the grain of barley was effective in mapping QTL. An additional locus in the $1 \mathrm{H}$ chromosome at 100.45 cM (SCRI_RS_6913) was detected on the same map location of SCRI_RS_171501 and two loci were found on the 3H chromosome at 82.19 (SCRI_RS_826) and $93.23 \mathrm{cM}$ (SCRI_RS_93.23). In 1H, SCRI_RS_171501 was an orthologous to Brachypodium distachyon LOC100846300 (MATH domaincontaining protein like At5g43560). These additional loci may also play important roles in modulating the fertility of lateral spikelets in barley.

In this study, 45 QTL were mapped in barley chromosomes for 13 element contents in barley grains. Our study is much more 
Table 3

Significant SNP-element content association analyzed for barley grain in Jemma Shiam and Marchouch stations in Morocco.

\begin{tabular}{|c|c|c|c|c|c|c|c|c|c|}
\hline \multirow[t]{2}{*}{ QTL } & \multirow{2}{*}{$\frac{{ }^{\mathrm{a}} \text { Element }}{\text {-Location }}$} & \multirow[t]{2}{*}{ SNP ID } & \multirow[t]{2}{*}{${ }^{\mathrm{b}} \mathrm{SNP}$} & \multirow[t]{2}{*}{${ }^{\mathrm{c}} \mathrm{CH}$} & \multirow[t]{2}{*}{$\mathrm{cM}$} & \multirow[t]{2}{*}{${ }^{\mathrm{d}} P$-value } & $R^{2}$ & ${ }^{\mathrm{e}}$ Additive & ${ }^{\mathrm{f}}$ Allele \\
\hline & & & & & & & & Effect & Freq. \\
\hline Ba-3H-15.52 & Ba-JS & 11_20595 & $\mathrm{A} / \mathrm{C}$ & $3 \mathrm{H}$ & 15.52 & $8.6 \mathrm{E}-04^{*}$ & 3.6 & 0.66 & $C=143$ \\
\hline$B a-3 H-8.5$ & Ba-JS & SCRI_RS_193258 & $\mathrm{A} / \mathrm{C}$ & $3 \mathrm{H}$ & 8.5 & $4.4 \mathrm{E}-04^{*}$ & 4 & 0.64 & $A=172$ \\
\hline $\mathrm{Ba}-3 \mathrm{H}-8.5$ & Ba-JS & SCRI_RS_230638 & $\mathrm{T} / \mathrm{G}$ & $3 \mathrm{H}$ & 8.5 & $5.3 \mathrm{E}-04^{*}$ & 3.9 & 0.67 & $\mathrm{~T}=177$ \\
\hline$B a-4 H-112.36$ & Ba-JS & SCRI_RS_222936 & $\mathrm{T} / \mathrm{C}$ & $4 \mathrm{H}$ & 112.36 & $3.2 \mathrm{E}-04^{*}$ & 4.1 & 0.73 & $C=163$ \\
\hline$B a-5 H-90.22$ & Ba-JS & $11 \_20805$ & $\mathrm{~A} / \mathrm{G}$ & $5 \mathrm{H}$ & 90.22 & $8.6 \mathrm{E}-05^{* *}$ & 4.9 & -0.97 & $A=261$ \\
\hline Вa-5H-90.22 & Ba-JS & SCRI_RS_13960 & $\mathrm{T} / \mathrm{C}$ & $5 \mathrm{H}$ & 90.22 & $1.1 \mathrm{E}-05^{* *}$ & 6.1 & -0.89 & $C=170$ \\
\hline Ba-5H-90.22 & Ba-JS & SCRI_RS_165215 & $\mathrm{T} / \mathrm{C}$ & $5 \mathrm{H}$ & 90.22 & $8.9 \mathrm{E}-07^{* *}$ & 7.7 & -1.04 & $C=196$ \\
\hline Ba-5H-95.49 & $\mathrm{Ba}-\mathrm{JS}$ & SCRI_RS_224346 & $\mathrm{T} / \mathrm{C}$ & $5 \mathrm{H}$ & 95.49 & $2.3 \mathrm{E}-05^{* *}$ & 5.7 & -1.06 & $C=263$ \\
\hline Ba-5H-95.9 & Ba-JS & SCRI_RS_157181 & $\mathrm{C} / \mathrm{G}$ & $5 \mathrm{H}$ & 95.9 & $2.3 \mathrm{E}-05^{* *}$ & 5.7 & -1.02 & $G=260$ \\
\hline $\mathrm{Ca}-2 \mathrm{H}-126.56$ & Ca-JS & SCRI_RS_219799 & $\mathrm{T} / \mathrm{C}$ & $2 \mathrm{H}$ & 126.56 & $9.0 \mathrm{E}-04^{*}$ & 3.5 & -42.17 & $C=219$ \\
\hline${ }^{g} E-3 H-153.39$ & Ca-JS & 12_30736 & $\mathrm{A} / \mathrm{G}$ & $3 \mathrm{H}$ & 153.39 & 7.9E-04* & 3.5 & 40.99 & $A=203$ \\
\hline$C u-6 H-50.61$ & $\mathrm{Cu}-\mathrm{JS}$ & SCRI_RS_150028 & $\mathrm{T} / \mathrm{C}$ & $6 \mathrm{H}$ & 50.61 & 8.3E-04* & 3.6 & -0.66 & $C=227$ \\
\hline $\mathrm{Cu}-6 \mathrm{H}-52.2$ & $\mathrm{Cu}-\mathrm{JS}$ & $11 \_10244$ & $\mathrm{~A} / \mathrm{T}$ & $6 \mathrm{H}$ & 52.2 & $4.8 \mathrm{E}-04^{*}$ & 3.9 & 0.68 & $A=94$ \\
\hline $\mathrm{Cu}-6 \mathrm{H}-58.91$ & $\mathrm{Cu}-\mathrm{JS}$ & 12_11140 & $\mathrm{A} / \mathrm{G}$ & $6 \mathrm{H}$ & 58.91 & $9.3 \mathrm{E}-04^{*}$ & 3.6 & -0.77 & $A=83$ \\
\hline${ }^{g} E-3 H-66.15$ & $\mathrm{Cu}-\mathrm{JS}$ & $11 \_10813$ & $\mathrm{~A} / \mathrm{G}$ & $3 \mathrm{H}$ & 66.15 & $7.6 \mathrm{E}-04^{*}$ & 3.7 & 0.7 & $A=64$ \\
\hline${ }^{\mathrm{g}} \mathrm{Fe}-2 \mathrm{H}-114.24$ & Fe-JS & SCRI_RS_708 & $\mathrm{A} / \mathrm{G}$ & $2 \mathrm{H}$ & 114.24 & $8.2 \mathrm{E}-04^{*}$ & 3.5 & 3.44 & $G=116$ \\
\hline $\mathrm{Fe}-2 \mathrm{H}-117.39$ & $\mathrm{Fe}-\mathrm{JS}$ & SCRI_RS_168451 & $\mathrm{C} / \mathrm{G}$ & $2 \mathrm{H}$ & 117.39 & $3.7 \mathrm{E}-04^{*}$ & 4 & 3.58 & $C=134$ \\
\hline $\mathrm{Fe}-2 \mathrm{H}-139.62$ & Fe-JS & 12_30097 & $\mathrm{C} / \mathrm{G}$ & $2 \mathrm{H}$ & 139.62 & $1.6 \mathrm{E}-04^{*}$ & 4.5 & -5.86 & $G=291$ \\
\hline${ }^{\mathrm{h}} \mathrm{Fe}-2 \mathrm{H}-84.74$ & Fe-JS & $12 \_11388$ & $\mathrm{~A} / \mathrm{G}$ & $2 \mathrm{H}$ & 84.74 & $2.8 \mathrm{E}-04^{*}$ & 4.2 & -7.36 & $G=291$ \\
\hline $\mathrm{Fe}-3 \mathrm{H}-83.63$ & Fe-JS & SCRI_RS_234564 & $\mathrm{A} / \mathrm{G}$ & $3 \mathrm{H}$ & 83.63 & $5.1 \mathrm{E}-04^{*}$ & 3.8 & -3.71 & $A=144$ \\
\hline $\mathrm{Fe}-4 \mathrm{H}-67.91$ & Fe-JS & $12 \_20143$ & $\mathrm{~A} / \mathrm{G}$ & $4 \mathrm{H}$ & 67.91 & $7.6 \mathrm{E}-04^{*}$ & 3.6 & -4.03 & $\mathrm{G}=115$ \\
\hline$E-4 H-54.95$ & Fe-MCH & $12 \_31462$ & $\mathrm{C} / \mathrm{G}$ & $4 \mathrm{H}$ & 54.95 & $1.10 \mathrm{E}-03$ & 3.3 & -7.59 & $C=224$ \\
\hline $\mathrm{Fe}-1 \mathrm{H}-54.5$ & $\mathrm{Fe}-\mathrm{MCH}$ & SCRI_RS_145305 & $\mathrm{A} / \mathrm{C}$ & $1 \mathrm{H}$ & 54.5 & $6.9 \mathrm{E}-04^{*}$ & 3.5 & -7.47 & $A=216$ \\
\hline $\mathrm{Fe}-1 \mathrm{H}-57.85$ & $\mathrm{Fe}-\mathrm{MCH}$ & SCRI_RS_237999 & $\mathrm{A} / \mathrm{G}$ & $1 \mathrm{H}$ & 57.85 & $9.7 \mathrm{E}-05^{* *}$ & 4.6 & -8.94 & $A=215$ \\
\hline $\mathrm{Fe}-1 \mathrm{H}-86.54$ & $\mathrm{Fe}-\mathrm{MCH}$ & SCRI_RS_181300 & $\mathrm{A} / \mathrm{G}$ & $1 \mathrm{H}$ & 86.54 & $3.9 \mathrm{E}-04^{*}$ & 3.8 & -7.17 & $G=241$ \\
\hline $\mathrm{Fe}-1 \mathrm{H}-87.87$ & $\mathrm{Fe}-\mathrm{MCH}$ & SCRI_RS_168562 & $\mathrm{C} / \mathrm{G}$ & $1 \mathrm{H}$ & 87.87 & $2.1 \mathrm{E}-04^{*}$ & 4.2 & -7.27 & $G=229$ \\
\hline $\mathrm{Fe}-1 \mathrm{H}-90.04$ & $\mathrm{Fe}-\mathrm{MCH}$ & SCRI_RS_189168 & $\mathrm{A} / \mathrm{G}$ & $1 \mathrm{H}$ & 90.04 & 7.3E-04* & 3.5 & 6.15 & $\mathrm{G}=198$ \\
\hline${ }^{\mathrm{h}} \mathrm{Fe}-2 \mathrm{H}-84.74$ & $\mathrm{Fe}-\mathrm{MCH}$ & $12 \_11388$ & $\mathrm{~A} / \mathrm{G}$ & $2 \mathrm{H}$ & 84.74 & 7.3E-04* & 3.5 & -12.9 & $\mathrm{G}=294$ \\
\hline $\mathrm{Fe}-4 \mathrm{H}-53.87$ & $\mathrm{Fe}-\mathrm{MCH}$ & 11_10946 & $\mathrm{A} / \mathrm{C}$ & $4 \mathrm{H}$ & 53.87 & $1.9 \mathrm{E}-04^{*}$ & 4.2 & -7.18 & $C=213$ \\
\hline $\mathrm{Fe}-4 \mathrm{H}-53.87$ & $\mathrm{Fe}-\mathrm{MCH}$ & $12 \_30684$ & $\mathrm{~A} / \mathrm{G}$ & $4 \mathrm{H}$ & 53.87 & $1.1 \mathrm{E}-04^{*}$ & 4.6 & -7.5 & $A=215$ \\
\hline $\mathrm{Fe}-4 \mathrm{H}-53.87$ & $\mathrm{Fe}-\mathrm{MCH}$ & SCRI_RS_157396 & $\mathrm{T} / \mathrm{C}$ & $4 \mathrm{H}$ & 53.87 & $1.9 \mathrm{E}-04^{*}$ & 4.2 & -7.18 & $C=213$ \\
\hline $\mathrm{Fe}-4 \mathrm{H}-53.87$ & $\mathrm{Fe}-\mathrm{MCH}$ & SCRI_RS_170494 & $\mathrm{A} / \mathrm{C}$ & $4 \mathrm{H}$ & 53.87 & $3.7 \mathrm{E}-04^{*}$ & 3.9 & -6.57 & $C=199$ \\
\hline $\mathrm{Fe}-4 \mathrm{H}-53.87$ & $\mathrm{Fe}-\mathrm{MCH}$ & SCRI_RS_171142 & $\mathrm{T} / \mathrm{C}$ & $4 \mathrm{H}$ & 53.87 & $1.1 \mathrm{E}-04^{*}$ & 4.6 & -7.5 & $C=214$ \\
\hline $\mathrm{Fe}-6 \mathrm{H}-102.03$ & $\mathrm{Fe}-\mathrm{MCH}$ & $12 \_31115$ & $\mathrm{~A} / \mathrm{G}$ & $6 \mathrm{H}$ & 102.03 & $5.5 \mathrm{E}-05^{* *}$ & 5 & -7.18 & $G=162$ \\
\hline $\mathrm{Fe}-7 \mathrm{H}-17.62$ & $\mathrm{Fe}-\mathrm{MCH}$ & SCRI_RS_222330 & $\mathrm{T} / \mathrm{C}$ & $7 \mathrm{H}$ & 17.62 & $9.7 \mathrm{E}-04^{*}$ & 3.3 & -6.41 & $C=201$ \\
\hline${ }^{g} E-3 H-153.39$ & K-JS & $12 \_10629$ & $\mathrm{~A} / \mathrm{C}$ & $3 \mathrm{H}$ & 153.39 & $4.3 \mathrm{E}-04^{*}$ & 3.9 & -424.11 & $A=284$ \\
\hline$K-1 H-131.94$ & K-JS & SCRI_RS_132472 & $\mathrm{T} / \mathrm{G}$ & $1 \mathrm{H}$ & 131.94 & $5.5 \mathrm{E}-07^{* *}$ & 8.1 & -408.43 & $\mathrm{~T}=218$ \\
\hline$K-5 H-95.65$ & K-JS & 11_10477 & $\mathrm{A} / \mathrm{G}$ & $5 \mathrm{H}$ & 95.65 & $7.1 \mathrm{E}-04^{*}$ & 3.6 & -266.63 & $\mathrm{~A}=184$ \\
\hline$K-5 H-97.35$ & K-JS & SCRI_RS_44800 & $\mathrm{A} / \mathrm{G}$ & $5 \mathrm{H}$ & 97.35 & $5.8 \mathrm{E}-04^{*}$ & 3.7 & -270.8 & $G=179$ \\
\hline K-5H-99.93 & $\mathrm{K}-\mathrm{JS}$ & SCRI_RS_149479 & $\mathrm{T} / \mathrm{C}$ & $5 \mathrm{H}$ & 99.93 & 7.1E-04* & 3.6 & -266.75 & $\mathrm{~T}=181$ \\
\hline${ }^{g} E-3 H-66.15$ & $\mathrm{Mg}-\mathrm{JS}$ & $11 \_10813$ & $\mathrm{~A} / \mathrm{G}$ & $3 \mathrm{H}$ & 66.15 & $4.0 \mathrm{E}-04^{*}$ & 4 & 97.07 & $A=64$ \\
\hline${ }^{g} E-7 H-1$ & Mg-JS & BOPA2_12_21479 & $\mathrm{A} / \mathrm{G}$ & $7 \mathrm{H}$ & i $58706384-58706385$ & 3.3E-04* & 4.1 & -103.01 & $A=258$ \\
\hline${ }^{g} E-7 H-95.02$ & Mg-JS & $11 \_21201$ & $\mathrm{~A} / \mathrm{G}$ & $7 \mathrm{H}$ & 95.02 & $6.5 \mathrm{E}-04^{*}$ & 3.7 & -91.63 & $A=252$ \\
\hline$K-7 H-86.56$ & Mg-JS & BOPA1_3568-149 & $\mathrm{A} / \mathrm{G}$ & $7 \mathrm{H}$ & 86.58 & 7.1E-04* & 3.6 & -110.77 & $A=285$ \\
\hline$M g-2 H-66.61$ & $\mathrm{Mg}-\mathrm{JS}$ & SCRI_RS_6792 & $\mathrm{T} / \mathrm{C}$ & $2 \mathrm{H}$ & 66.61 & $8.2 \mathrm{E}-04^{*}$ & 3.6 & -67.06 & $\mathrm{~T}=194$ \\
\hline${ }^{2}-7 H-1$ & Mn-JS & BOPA2_12_21479 & $\mathrm{A} / \mathrm{G}$ & $7 \mathrm{H}$ & ${ }^{\mathrm{i}} 58706384-58706385$ & $1.1 \mathrm{E}-04^{*}$ & 4.9 & -1.61 & $A=258$ \\
\hline${ }^{g} E-7 H-95.02$ & Mn-JS & $11 \_21201$ & $\mathrm{~A} / \mathrm{G}$ & $7 \mathrm{H}$ & 95.02 & $1.3 \mathrm{E}-04^{*}$ & 4.8 & -1.53 & $A=252$ \\
\hline$M n-3 H-74.41$ & Mn-JS & SCRI_RS_202772 & $\mathrm{A} / \mathrm{G}$ & $3 \mathrm{H}$ & 74.41 & $4.8 \mathrm{E}-04^{*}$ & 3.8 & 1.13 & $G=186$ \\
\hline$M n-4 H-60.70$ & Mn-JS & $11 \_10846$ & $\mathrm{C} / \mathrm{G}$ & $4 \mathrm{H}$ & 60.72 & $8.0 \mathrm{E}-04^{*}$ & 3.6 & -1.42 & $C=271$ \\
\hline$M n-7 H-82.16$ & Mn-JS & 11_20880 & $\mathrm{A} / \mathrm{G}$ & $7 \mathrm{H}$ & 82.16 & $1.2 \mathrm{E}-04^{*}$ & 4.7 & -1.44 & $A=232$ \\
\hline$M n-7 H-82.16$ & Mn-JS & 12_30998 & $\mathrm{A} / \mathrm{G}$ & $7 \mathrm{H}$ & 82.16 & $1.2 \mathrm{E}-04^{*}$ & 4.7 & -1.44 & $A=232$ \\
\hline$M n-7 H-85.87$ & Mn-JS & 12_30301 & $\mathrm{A} / \mathrm{G}$ & $7 \mathrm{H}$ & 85.87 & $8.2 \mathrm{E}-04^{*}$ & 3.5 & -2.03 & $A=293$ \\
\hline$M n-7 H-91.73$ & Mn-JS & $12 \_11044$ & $\mathrm{~A} / \mathrm{C}$ & $7 \mathrm{H}$ & 91.73 & $6.3 \mathrm{E}-05^{* *}$ & 5.2 & -1.75 & $C=273$ \\
\hline${ }^{\mathrm{g}} \mathrm{E}-1 \mathrm{H}-1$ & Na-JS & SCRI_RS_185604 & $\mathrm{A} / \mathrm{G}$ & $1 \mathrm{H}$ & 550548357-550548566 & $4.8 \mathrm{E}-04^{*}$ & 3.8 & 333.53 & $G=287$ \\
\hline${ }^{g} E-3 H-66.15$ & Na-JS & $11 \_10813$ & $\mathrm{~A} / \mathrm{G}$ & $3 \mathrm{H}$ & 66.15 & $1.1 \mathrm{E}-04^{*}$ & 4.8 & 328.43 & $A=64$ \\
\hline${ }^{g} E-5 H-44.99$ & Na-JS & $11 \_11221$ & $\mathrm{~A} / \mathrm{C}$ & $5 \mathrm{H}$ & 44.99 & $9.8 \mathrm{E}-05^{* *}$ & 4.8 & 312.62 & $A=112$ \\
\hline $\mathrm{Na}-5 \mathrm{H}-1.12$ & Na-JS & SCRI_RS_137053 & $\mathrm{T} / \mathrm{C}$ & $5 \mathrm{H}$ & 1.12 & $3.7 \mathrm{E}-04^{*}$ & 4 & 45.91 & $C=251$ \\
\hline $\mathrm{Na}-7 \mathrm{H}-82.89$ & Na-JS & SCRI_RS_230083 & $\mathrm{A} / \mathrm{G}$ & $7 \mathrm{H}$ & 82.89 & $6.0 \mathrm{E}-04^{*}$ & 3.7 & 50.15 & $A=64$ \\
\hline${ }^{g} E-4 H-111.97$ & Se-JS & SCRI_RS_140963 & $\mathrm{T} / \mathrm{C}$ & $4 \mathrm{H}$ & 111.97 & $4.0 \mathrm{E}-04^{*}$ & 3.9 & -0.16 & $C=212$ \\
\hline${ }^{g} E-7 H-95.02$ & Si-JS & $11 \_21201$ & $\mathrm{~A} / \mathrm{G}$ & $7 \mathrm{H}$ & 95.02 & $9.8 \mathrm{E}-04^{*}$ & 3.4 & 58.73 & $A=252$ \\
\hline$S i-4 H-103.38$ & Si-JS & SCRI_RS_148330 & $\mathrm{A} / \mathrm{T}$ & $4 \mathrm{H}$ & 103.48 & $2.0 \mathrm{E}-04^{*}$ & 4.4 & -78.14 & $\mathrm{~T}=279$ \\
\hline Si-4H-103.38 & Si-JS & SCRI_RS_157611 & $\mathrm{T} / \mathrm{C}$ & $4 \mathrm{H}$ & 103.38 & $2.0 \mathrm{E}-04^{*}$ & 4.4 & -78.14 & $C=279$ \\
\hline $\mathrm{Si}-4 \mathrm{H}-88.84$ & Si-JS & SCRI_RS_107010 & $\mathrm{T} / \mathrm{C}$ & $4 \mathrm{H}$ & 88.84 & $5.8 \mathrm{E}-04^{*}$ & 3.7 & -62.92 & $C=256$ \\
\hline Si-5H-185.05 & Si-JS & SCRI_RS_239569 & $\mathrm{T} / \mathrm{C}$ & $5 \mathrm{H}$ & 185.05 & $2.9 \mathrm{E}-04^{*}$ & 4.1 & -57.58 & $\mathrm{~T}=129$ \\
\hline Si-6H-55.11 & Si-JS & SCRI_RS_168964 & $\mathrm{A} / \mathrm{G}$ & $6 \mathrm{H}$ & 55.11 & $5.3 \mathrm{E}-04^{*}$ & 3.8 & 55.34 & $G=86$ \\
\hline $\mathrm{Si}-7 \mathrm{H}-1$ & Si-JS & BOPA2_12_30790 & $\mathrm{A} / \mathrm{G}$ & $7 \mathrm{H}$ & ${ }^{\mathrm{i}} 496253212-496253213$ & $5.8 \mathrm{E}-04^{*}$ & 3.7 & 98.91 & $G=298$ \\
\hline $\mathrm{Si}-7 \mathrm{H}-81.07$ & Si-JS & $11 \_10069$ & $\mathrm{C} / \mathrm{G}$ & $7 \mathrm{H}$ & 81.07 & $2.7 \mathrm{E}-05^{* *}$ & 5.6 & 88.79 & $C=273$ \\
\hline Si-7H-81.07 & Si-JS & $11 \_10673$ & $\mathrm{~A} / \mathrm{G}$ & $7 \mathrm{H}$ & 81.07 & $2.2 \mathrm{E}-05^{* *}$ & 5.7 & 71.39 & $A=224$ \\
\hline Si-7H-86.58 & Si-JS & BOPA1_3568-149 & $\mathrm{A} / \mathrm{G}$ & $7 \mathrm{H}$ & 86.58 & $3.5 \mathrm{E}-04^{*}$ & 4 & 77.89 & $A=285$ \\
\hline Si-7H-91.09 & Si-JS & SCRI_RS_4562 & $\mathrm{A} / \mathrm{C}$ & $7 \mathrm{H}$ & 91.09 & $1.6 \mathrm{E}-04^{*}$ & 4.5 & 66.01 & $A=252$ \\
\hline${ }^{g} E-1 H-1$ & S-JS & SCRI_RS_185604 & $\mathrm{A} / \mathrm{G}$ & $1 \mathrm{H}$ & ${ }^{\mathrm{i}} 550548357-550548566$ & $5.0 \mathrm{E}-04^{*}$ & 3.8 & 108.07 & $G=287$ \\
\hline${ }^{g} E-3 H-66.15$ & S-JS & $11 \_10813$ & $\mathrm{~A} / \mathrm{G}$ & $3 \mathrm{H}$ & 66.15 & 7.2E- $04^{*}$ & 3.7 & 95.14 & $A=64$ \\
\hline
\end{tabular}


Table 3 (continued)

\begin{tabular}{|c|c|c|c|c|c|c|c|c|c|}
\hline \multirow[t]{2}{*}{ QTL } & ${ }^{\mathrm{a}}$ Element & SNP ID & ${ }^{\mathrm{b}} \mathrm{SNP}$ & ${ }^{\mathrm{c}} \mathrm{CH}$ & cM & \multirow[t]{2}{*}{${ }^{\mathrm{d}} P$-value } & \multirow[t]{2}{*}{$R^{2}$} & \multirow{2}{*}{$\frac{{ }^{\mathrm{e}} \text { Additive }}{\text { Effect }}$} & \multirow{2}{*}{$\frac{{ }^{\mathrm{f}} \text { Allele }}{\text { Freq. }}$} \\
\hline & -Location & & & & & & & & \\
\hline${ }^{g} E-4 H-111.97$ & S-JS & SCRI_RS_140963 & $\mathrm{T} / \mathrm{C}$ & $4 \mathrm{H}$ & 111.97 & 4.3E-04* & 3.9 & 83.19 & $C=212$ \\
\hline$S-1 H-50$ & S-JS & 11_10985 & $\mathrm{A} / \mathrm{C}$ & $1 \mathrm{H}$ & 50 & $3.5 \mathrm{E}-04^{*}$ & 4.1 & 117.91 & $C=233$ \\
\hline$S-4 H-117.13$ & S-JS & SCRI_RS_192456 & $\mathrm{T} / \mathrm{C}$ & $4 \mathrm{H}$ & 117.13 & $9.1 \mathrm{E}-04^{*}$ & 3.5 & -82 & $C=235$ \\
\hline S-4H-99.08 & S-JS & SCRI_RS_226787 & $\mathrm{A} / \mathrm{G}$ & $4 \mathrm{H}$ & 99.08 & $8.6 \mathrm{E}-04^{*}$ & 3.5 & 84 & $A=153$ \\
\hline${ }^{g} E-3 H-66.15$ & $\mathrm{Zn}-\mathrm{JS}$ & 11_10813 & $\mathrm{A} / \mathrm{G}$ & $3 \mathrm{H}$ & 66.15 & $5.8 \mathrm{E}-04^{*}$ & 3.7 & 2.38 & $A=64$ \\
\hline${ }^{g} E-5 H-44.99$ & Zn-JS & 11_11221 & $\mathrm{A} / \mathrm{C}$ & $5 \mathrm{H}$ & 44.99 & 7.9E-04* & 3.5 & 2.23 & $A=112$ \\
\hline $\mathrm{Zn}-4 \mathrm{H}-1.13$ & Zn-JS & SCRI_RS_126417 & $\mathrm{T} / \mathrm{G}$ & $4 \mathrm{H}$ & 1.13 & $8.5 \mathrm{E}-04^{*}$ & 6.2 & 3.51 & $G=151$ \\
\hline $\mathrm{Zn}-4 \mathrm{H}-1.13$ & Zn-JS & SCRI_RS_236981 & $\mathrm{T} / \mathrm{C}$ & $4 \mathrm{H}$ & 1.13 & $4.5 \mathrm{E}-04^{*}$ & 3.9 & 1.87 & $\mathrm{~T}=229$ \\
\hline${ }^{g} E-4 H-54.95$ & $\mathrm{Zn}-\mathrm{MCH}$ & 12_30839 & $\mathrm{A} / \mathrm{C}$ & $4 \mathrm{H}$ & 54.95 & $1.20 \mathrm{E}-03$ & 3.2 & -3.03 & $A=288$ \\
\hline $\mathrm{Zn}-1 \mathrm{H}-21.97$ & Zn-MCH & 11_20371 & $\mathrm{A} / \mathrm{G}$ & $1 \mathrm{H}$ & 21.97 & $1.90 \mathrm{E}-03$ & 3 & -3.69 & $A=313$ \\
\hline $\mathrm{Zn}-2 \mathrm{H}-148.16$ & Zn-MCH & SCRI_RS_154153 & $\mathrm{T} / \mathrm{C}$ & $2 \mathrm{H}$ & 148.16 & $1.20 \mathrm{E}-03$ & 3.2 & -2.04 & $C=205$ \\
\hline $\mathrm{Zn}-2 \mathrm{H}-40.12$ & $\mathrm{Zn}-\mathrm{MCH}$ & SCRI_RS_123295 & $\mathrm{T} / \mathrm{C}$ & $2 \mathrm{H}$ & 40.12 & $6.8 \mathrm{E}-04^{*}$ & 3.6 & -2.98 & $C=290$ \\
\hline $\mathrm{Zn}-2 \mathrm{H}-86.84$ & $\mathrm{Zn}-\mathrm{MCH}$ & SCRI_RS_139193 & $\mathrm{A} / \mathrm{G}$ & $2 \mathrm{H}$ & 86.84 & $1.10 \mathrm{E}-03$ & 3.3 & -2.92 & $A=192$ \\
\hline $\mathrm{Zn}-2 \mathrm{H}-87.34$ & Zn-MCH & SCRI_RS_166540 & $\mathrm{A} / \mathrm{G}$ & $2 \mathrm{H}$ & 87.34 & $1.6 \mathrm{E}-04^{*}$ & 4.4 & -3.15 & $A=204$ \\
\hline $\mathrm{Zn}-2 \mathrm{H}-87.34$ & Zn-MCH & SCRI_RS_2961 & $\mathrm{T} / \mathrm{C}$ & $2 \mathrm{H}$ & 87.34 & $7.0 \mathrm{E}-05^{* *}$ & 4.9 & -3.5 & $\mathrm{~T}=205$ \\
\hline
\end{tabular}

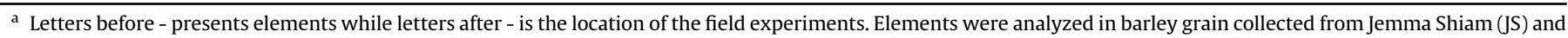
Marchouch (MCH) locations in Morocco.

b SNP- Single Nucleotide Polymorphism.

c CH-Barley Chromosome.

d FDR correction was performed on significant SNP markers where *, ${ }^{* *}$ are FDR corrections at $q=0.05$ and $q=0.01$ levels.

e Positive additive effect indicates increased element concentration whereas negative additive effects indicates deceased element concentration in barley grain.

f Allele Frequency contributing additive effects.

g QTL affecting multiple element content in barley grain.

h Bold faced QTL found in both Jemma Shiam and Marchouch locations.

i The SNP position was aligned with Morex genome sequence data base (http://floresta.eead.csic.es/barleymap/[visited August 22, 2017]) with start and ending position of SNP given.

comprehensive compared to previous studies because QTL were mapped for thirteen elements in barley grain using GWAS, with a focus on $\mathrm{Zn}$ and Fe. This study will help barley breeders around the world on biofortification efforts of multiple elements. A few studies have been conducted on mapping QTL of element contents in barley grains and many of them focused on $\mathrm{Zn}$ uptake. Mamo et al. (2014) mapped two QTL, Zn-qtl-6H_SCRI_RS_10655 at $122 \mathrm{cM}$ and Zn-qtl-6H_SCRI_RS_10655, at 128.72 cM for Zn uptake in the barley grain. Lonergan et al. (2009) reported nine QTL for Zn uptake and translocation of $\mathrm{Zn}$ in various plant parts, including roots, shoots, peduncles and grain. They reported that QTL in 1HS, 2HL, and 5HL were responsible for $\mathrm{Zn}$ translocation in barley grain, which is confirmed by our study. We found three QTL, $\mathrm{Zn}-1 \mathrm{H}-21.97$ and $\mathrm{Zn}$ $2 \mathrm{H}-87.34$, and $\mathrm{E}-5 \mathrm{H}-44.99$, involved in $\mathrm{Zn}$ uptake in the barley grain. Sadeghzadeh et al. (2010) mapped QTL on the 2HS chromosome for $\mathrm{Zn}$ uptake in grain using a bi-parental mapping population (Double Haploid of 'Clipper' [low Zn] x 'Sahara 3771' [high Zn]). They mapped $S Z n-R 1$ at $1.7 \mathrm{cM}$ of the $2 \mathrm{H}$ chromosome, which was different than the QTL $\mathrm{Zn}-2 \mathrm{H}-87.34$ mapped in our study in the same chromosome. In addition, recently Sadeghzadeh et al. (2015) mapped additional $\mathrm{Zn}$ QTL in $2 \mathrm{HL}, 3 \mathrm{H}$, and $4 \mathrm{H}$, using the same biparental mapping population (Clipper x Sahara 3771). Among the QTL mapped by Sadeghzadeh et al. (2015), two QTL mapped in 3H and $4 \mathrm{H}$ coincided with the QTL $E-3 H-66.15$ and $E-4 H-54.95$ mapped in our study, although $E-4 H-54.95$ was not significant at $q<0.05$ FDR. Likewise, Reuscher et al. (2016) reported 25, 16 and 5 QTL for $\mathrm{Zn}$, Fe and Cd accumulation in barley. Our results are consistent with Lonergan et al. (2009) while QTL reported by Mamo et al. (2014) were different. The GWAS panel used by Mamo et al. (2014) included only landraces from Ethiopia and Eritrea, while our mapping panel comprised of mostly advanced breeding lines of ICARDA barley breeding program, including cultivars released in several countries, and a few landraces which originated from Nepal, India, Mongolia, Morocco, and Central Asia. A wide variety of genes were annotated using the sequences of significant SNP markers in the BLAST search. The gene annotation reported in our study is highly valuable to our understanding of complex element uptake and translocation mechanisms in plants.

\section{Conclusions}

The major goal of our study was to identify and map QTL involved in uptake and translocation of elements in barley grains with, a focus on identifying $\mathrm{Zn}$ and Fe dense barley genotypes, so that this germplasm would be available to barley researchers across the globe through ICARDA networks. Currently, several countries such as Nepal, India, Tunisa, Morocco, Ethiopia, and others have directly utilized the AM-2014 in their breeding programs. Therefore, information on barley genotypes capable of higher element uptake in the grain and the markers (SNPs) associated with the QTL is invaluable for future barley breeding programs. The utility of the GWAS panel is more successful compared to previous approaches using wild barley, because QTL mapping in barley chromosomes was achieved using advanced breeding lines and released cultivars. Therefore, less linkage drag is expected in using this germplasm for bio-fortification of important elements such as $\mathrm{Zn}$ and Fe. The barley germplasm used in the AM-2014 panel and the SNP markers associated with the QTL for element uptake are publicly available through the barley breeding programs of ICARDA upon request. The information generated by our GWAS is highly useful to barley breeders across the globe for marker-assisted selection and genomic selections for dense micronutrients in the barley grains. Currently, three crosses Rihane-03 x Zanbaka, Alanda-01 x Zanbaka, and Rihane-03 x Alanda-01, were made in ICARDA to study and map $\mathrm{Zn}$ and Fe contents in barley grains by utilizing information in genotypes identified in this study. Double haploid populations were produced from these crosses to validate QTL detected in this study. Genotyping and phenotyping of these double haploid populations are on progress in ICARDA. Barley breeding has been initiated to recombine high $\mathrm{Fe}$ and $\mathrm{Zn}$ concentrtions with higher $\beta$ Glucan accumulating genotypes obtained from the USDA. 


\section{Acknowledgements}

This research was supported in part by USAID-Dryland Cereals partnership program and barley breeding programs of ICARDA (ARS CFDA\# 10001, 34071). USDA-ARS, Fargo, WERG of NDSU, Fargo, INRA-Maroc, Rabat is highly acknowledged for providing assistances in laboratory analyses.

\section{Appendix A. Supplementary data}

Supplementary data related to this article can be found at http:// dx.doi.org/10.1016/j.jcs.2017.08.019.

\section{References}

Amezrou, R., Gyawali, S., Belqadi, L., Chao, S., Arbaoui, M., Mamidi, S., Rehman, S., Sreedasyam, A., Verma, R.P.S., 2017. Molecular and phenotypic diversity of ICARDA spring barley (Hordeum vulgare L.) collection. Genet. Resour. Crop Evol. http://dx.doi.org/10.1007/s10722-017-0527-z (Accepted May 2017).

Bradbury, P.J., Zhang, Z., Kroon, D.E., Casstevens, T.M., Ramdoss, Y., Buckler, E.S. 2007. TASSEL: software for association mapping of complex traits in diverse samples. Bioinformatics 23, 2633-2635.

Cuesta-Marcos, A., Szucs, P., Close, T.J., Filichkin, T., Muehlbauer, G.J., Smith, K.P., Hayes, P.M., 2010. Genome-wide SNPs and re-sequencing of growth habit and inflorescence genes in barley: implications for association mapping in germplasm arrays varying in size and structure. BMC Genom. 11, 707.

Dick, A.C., Malhi, S.S., O'Sullivan, P.A., Walker, D.R., 1985. Chemical composition of whole plant and grain and yiled of nutrients in grains of five barley cultivars. Plant Soil 85, 257-264.

El-Haramein, F.J., Grando, S., 2010. Determination of Fe and $\mathrm{Zn}$ content in food barley. In: Ceccareli, S., Grando, S. (Eds.), Proceedings of the 10th International Barley Genetics Symposium, 5-10 April 2008, Alexandria, Egypt. ICARDA, PO Box 5466, Aleppo, Syria, pp. 603-606.

Evanno, G., Regnaut, S., Goudet, J., 2005. Detecting the number of clusters of individuals using the software STRUCTURE: a simulation study. Mol. Ecol. 14, 2611-2620.

FAOStat, 2014. Food and Agriculture Organization of the United Nations. Statistics Division. Rome, Italy. http://faostat3.fao.org/browse/Q/QC/E. (Accessed 1 March 2017).

Hussain, S., Rengel, Z., Mohammadi, S.A., Ebadi-Segherloo, A., Maqsood, M.A., 2016. Mapping QTL associated with remobilization of zinc from vegetative tissues into grains of barley (Hordeum vulgare). Plant Soil 399, 193-208. http:// dx.doi.org/10.1007/s11104-015-2684-1.

Lonergan, P.F., Pallotta, M.A., Lorimer, M., Paull, J.G., Barker, S.J., Graham, R.D., 2009. Multiple genetic loci for zinc uptake and distribution in barley (Hordeum vulgare). New Phytol. 184, 168-179. http://dx.doi.org/10.1111/j.14698137.2009.02956.x.

Ma, J.F., Higashitani, A., Sato, K., Takeda, K., 2004. Genotyping variation in Fe concentration in barley grain. Soil Sci. Plant Nutr. 50 (7), 1115-1117.

Mamo, B.E., Barber, B.L., Steffenson, B.J., 2014. Genome-wide association mapping of zinc and iron concentration in barley landraces from Ethiopia and Eritrea. J. Cereal Sci. 60, 497-506.

Markert, B., 1992. Establishment of 'reference plant' for inorganic characterization of different plant species by chemical fingerprinting. Water Air Soil Pollut. 64, $533-538$.

Marler, J.B., Wallin, J.R., 2006. Human Health, the Nutritional Quality of Harvested Food and Sustainable Farming Systems. White paper. US Senate Document \# 264-1936.

Masuda, H., Suzuki, M., Morikawa, K.C., Kobayashi, T., Nakanishi, H., Takahashi, M. Saigusa, M., Mori, S., Nishizawa, N.K., 2008. Increase in Iron and Zinc concentrations in rice grains via the introduction of barley genes involved in phytosiderophore synthesis. Rice 1, 100-108. http://dx.doi.org/10.1007/s12284008-9007-6.

Miller, D.D., Rutzke, M.A., 2003. Atomic absorption and emission spectroscopy. In: Nielsen, S.S. (Ed.), Food Analysis, third ed. Kluwer Academic, New York pp. $401-421$

Monasterio, I., Graham, R.D., 2000. Breeding for trace minerals in wheat. Food Nutr Bull. 21, 392-396.

Murphy, K.M., Reeves, P.G., Jones, S.S., 2008. Relationship between yield and mineral nutrient concentrations in historical and modern spring wheat cultivars. Euphytica 163, 381-390.

Nakanishi, H., Yamaguchi, H., Sasakuma, T., Nishizawa, N.K., Mori, S., 2000. Two dioxygenase genes, Ids3 and Ids2, from Hordeum vulgare are involved in the biosynthesis of mugineic acid family phytosiderophores. Plant Mol. Biol. 44, 199-207.

Newman, C., Newman, R., 2006. A brief history of barley foods. Cereal Foods World $51,4 \mathrm{e} 7$.

Otte, M.L., Jacob, D.L., 2005. Chemical fingerprinting of plants from contrasting wetlands - salt marsh, geothermal and mining-impacted. Phyton 45, 303-316.

Prasad, A.S., 1991. Discovery of human zinc deficiency and studies in an experimental human model. Am. J. Clin. Nutr. 53, 403-412.

Pritchard, J.K., Stephens, M., Donnelly, P., 2000. Inference of population structure using multilocus genotype data. Genetics 155, 945-959.

Quinde, Z., Ullrich, S.E., Baik, B.K., 2004. Genotypic variation in colour and discolouration potential of barley based food products. Cereal Chem. 81, 752-758.

Ramsay, L., Comadran, J., Druka, A., Marshall, D.F., Thomas, W.T., Macaulay, M. MacKenzie, K., Simpson, C., Fuller, J., Bonar, N., 2011. INTERMEDIUM-C, a modifier of lateral spikelet fertility in barley, is an ortholog of the maize domestication gene TEOSINTE BRANCHED 1. Nat. Genet. 43, 169-172.

Reuscher, S., Kolter, A., Hoffmann, A., Pillen, K., Krämer, U., 2016. Quantitative trait loci and inter-organ partitioning for essential metal and toxic analogue accumulation in barley. PLoS One 11 (4), e0153392. http://dx.doi.org/10.1371/ journal.pone.0153392.

Sadeghzadeh, B., Rengel, Z., Li, C., 2015. Quantitative trait loci (QTL) of seed Zn accumulation in barley population Clipper x Sahara. J. Plant Nutr. 38 (11) 1672-1684. http://dx.doi.org/10.1080/01904167.2014.991036.

Sadeghzadeh, B., Rengel, Z., Li, C., Yang, H., 2010. Molecular marker linked to a chromosome region regulating seed $\mathrm{Zn}$ accumulation in barley. Mol. Breed. 25, $167-177$.

Sandstead, H.H., 1991. Zinc deficiency: a public health problem? Am. J. Dis. Child $145,853-859$.

SAS Institute Inc., 1999. SAS/STAT user's guide. Vers. 8. SAS Institute Inc, Cay, NC.

Slotta, T.A.B., Brady, L., Chao, S., 2008. High throughput tissue preparation for largescale genotyping experiments. Mole. Ecol. Resour. 8, 83-87. http://dx.doi.org 10.1111/j.1471-8286.2007.01907.x.

Stoltzfus, R.J., Dreyfuss, M.L., 1998. Guidelines for the Use of Iron Supplements to Prevent and Treat Iron Deficiency Anemia. ILSI Press, Washington, DC.

Storey, J.D., 2002. A direct approach to false discovery rates. J. R. Stat. Soc. B 64 (3), 479-498.

Takahashi, M., Yamaguchi, H., Nakanishi, H., Shioiri, T., Nishizawa, N.K., Mori, S., 1999. Cloning two genes for nicotianamine aminotransferase, a critical enzyme in iron acquisition (Strategy II) in graminaceous plants. Plant Physiol. 121, 947-956.

Welch, R.M., Graham, R.D., 2004. Breeding for micronutrients in staple food crops from a human nutrition perspective. J. Exp. Bot. 55 (396), 353-364. http:/ dx.doi.org/10.1093/jxb/erh064.

WHO, 2002. World Health Report Reducing Risks, Promoting Healthy Life. WHO Geneva, Switzerland.

Wu, F., Zhang, G., 2002. Genotypic variation in kernel heavy metals concentrations in barley and as affected by soil factors. J. Plant Nutr. 25 (6), 1163-1173. http:/ dx.doi.org/10.1081/PLN-120004380.

Yan, J., Wang, F., Yang, R., Xiao, T., Fahima, T., Saranga, Y., Korol, A., Nevo, E., Cheng, J., 2012. Natural variation in grain iron and zinc concentrations of wild barley, Hordeum spontaneum, populations from Israel. In: Zhang, G., Li, C., Liu, X. (Eds.), Advance in Barley Sciences, Proceedings of 11 th International Barley Genetics Symposium. Springer, pp. 169-183. 